Jurnal Pemberdayaan: Publikasi Hasil Pengabdian kepada Masyarakat

Vol. 3, No.2, Agustus 2019, Hal. 251-254

ISSN: 2580-2569; e-ISSN: 2656-0542

DOI: https://doi.org/10.12928/jp.v3i2.551

\title{
Sosialisasi tentang keluarga berencana dan jenis kontrasepsi di Desa Jambidan Kecamatan Banguntapan, Bantul
}

\author{
Suci Musvita Ayu \\ Universitas Ahmad Dahlan, Jl. Prof. DR. Soepomo Sh, Kota Yogyakarta, 55164 \\ Email: suci.ayu@ikm.uad.ac.id
}

\begin{abstract}
ABSTRAK
Program Keluarga Berencana mempunyai kontribusi penting dalam upaya meningkatkan kualitas penduduk. Untuk mengoptimalkan manfaat keluarga berencana bagi kesehatan, pelayanannya harus digabungkan dengan pelayanan kesehatan reproduksi. Penyuluhan ini dilakukan pada tanggal 11-12 Juli 2018. Metode yang digunakan adalah dengan memberikan penyuluhan secara langsung kepada masyarakat umum dengan materi keluarga berencana dan jenis kontrasepsi menggunakan metode ceramah, diskusi, tanya jawab. Hasil yang diperoleh adalah kegiatan penyuluhan berjalan dengan baik dan peserta aktif mengikuti kegiatan penyuluhan sampai selesai. Penyuluhan dilakukan dengan interaktif antara narasumber dengan peserta yang hadir.
\end{abstract}

Kata kunci: Keluarga Berencana, Kesehatan Reproduksi, Penyuluhan

\begin{abstract}
The Family Planning Program has an important contribution in efforts to improve the quality of the population. To optimize the benefits of family planning for health, its services must be combined with reproductive health services. This Counseling was conducted on July 12, 2018. The method used is to provide counseling directly to the general public with family planning material and types of contraception using the lecture method, discussion, question and answer. The results obtained were counseling activities went well and the participants actively participated in counseling activities to completion. Counseling is carried out interactively between speakers and participants.
\end{abstract}

Keywords: Family Planning, Reproductive Health, Counseling 


\section{PENDAHULUAN}

Tingginya laju pertumbuhan penduduk dan kurang seimbangnya penyebaran dan struktur umur penduduk masih merupakan masalah utama yang sedang dihadapi negara berkembang termasuk Indonesia. Jumlah penduduk yang besar tanpa diiringi kualitas sumber daya manusia yang baik mempersulit usaha peningkatan dan pemerataan kesejahteraan rakyat (BKKBN, 2007). Salah satu usaha untuk menanggulangi masalah kependudukan tersebut adalah dengan mengikuti program Keluarga Berencana (KB). Semakin tinggi pertumbuhan penduduk semakin besar usaha yang diperlukan untuk mempertahankan tingkat kesejahteraan rakyat (Handayani, 2010).

Program KB ini dimaksudkan untuk membantu pasangan dan perorangan dalam tujuan kesehatan reproduksi yang berkualitas (BKKBN, 2008). Selain itu melalui program ini dapat menurunkan tingkat/angka kematian ibu, bayi, dan anak serta penanggulangan masalah kesehatan reproduksi dalam rangka membangun keluarga kecil berkualitas, dan untuk mempersiapkan kehidupan dalam mendukung upaya peningkatan kualitas generasi mendatang (Noviawati, 2011).

Keluarga berencana merupakan usaha untuk menjarangkan jumlah anak dan jarak kelahiran anak yang diinginkan. Maka dari itu, pemerintah mencanangkan program atau cara untuk mencegah dan menunda kehamilan (Sulistyawati, 2011). Tujuan utama pelaksanaan keluarga berencana dalam Repelita I adalah untuk meningkatkan derajat kesehatan dan kesejahteraan ibu dan anak, keluarga serta masyarakat pada umumnya. Dengan berhasilnya pelaksanaan keluarga berencana diharapkan angka kelahiran dapat diturunkan, sehingga tingkat kecepatan perkembangan penduduk tidak melebihi kemampuan kenaikan produksi. Dengan demikian taraf kehidupan dan kesejahteraan rakyat diharapkan akan lebih meningkat (BKKBN, 2012).

Program keluarga berencana dilaksanakan atas dasar suka-rela serta tidak bertentangan dengan agama, kepercayaan dan moral Pancasila. Dengan demikian maka bimbingan, pendidikan serta pengarahan amat diperlukan agar masyarakat dengan kesadarannya sendiri dapat menghargai dan, menerima pola keluarga kecil sebagai salah satu langkah utama untuk meningkatkan kesejahteraan hidupnya. Oleh karena itu pelaksanaan program keluarga berencana tidak hanya menyangkut masalah tehnis medis semata-mata, melainkan meliputi berbagai segi penting lainnya dalam tata hidup dan kehidupan masyarakat (BKKBN, 2007).

Organisasi pelaksanaan keluarga berencana dalam Repelita I mengalami perkembanganperkembangan. Kegiatan secara terorganisir mulai dirintis dengan didirikannya Perkumpulan Keluarga Berencana Indonesia (PKBI) pada tahun 1957 (PKBI, 2010). Akan tetapi barulah sejak tahun 1968 dengan dibentuknya Lembaga Keluarga Berencana Nasional (LKBN), kegiatan keluarga berencana telah ditingkatkan menjadi suatu program nasional. Sesuai dengan perkembangan pelaksanaan keluarga berencana, dibutuhkan (penyempurnaan organisasi, sehingga dalam tahun 1970 LKBN telah dirubah menjadi Badan Koordinasi Keluarga Berencana Nasional (BKKBN). Selanjutnya dalam Repelita I terus dilakukan usaha-usaha penyempurnaan organisasi BKKBN.

Metode kontrasepsi mantap terdiri dari 2 macam yaitu Metode Operatif Wanita (MOW) dan Metode Operatif Pria (MOP). MOW sering dikenal dengan tubektomi karena prinsip metode ini adalah memotong atau mengikat saluran tuba/tuba falopii sehingga mencegah pertemuan antara ovum dan sperma. Sedangkan MOP sering dikenal dengan nama vasektomi, vasektomi yaitu memotong atau mengikat saluran vas deferenssehingga cairan sperma tidak dapat keluar atau ejakulasi.

\section{METODE}

Kegiatan ini menggunakan metode penyuluhan kepada masyarakat. Kegiatan ini dilakukan di balai Desa Jambidan Kecamatan Banguntapan, Bantul pada tanggal 11-12 Juli 2018 dengan peserta berjumlah 37 orang dan mahasiswa yang terlibat sebanyak 9 orang. 
Pelaksanaan kegiatan adalah penyuluhan tentang keluarga berencana dan jenis kontrasepsi menggunakan metode ceramah, diskusi, tanya jawab.

\section{HASIL, PEMBAHASAN, DAN DAMPAK}

Penyuluhan yang diberikan sebagian besar merupakan materi tentang keluarga berencana dan jenis-jenis metode. KB adalah suatu usaha untuk mengatur jumlah dan jarak kehamilan anak, guna meningkatkan kesehatan dan kesejahteraan keluarga. Manfaat dari KB sendiri yaitu menghindari kehamilan risiko tinggi, menurunkan angka kematian ibu dan bayi, meringankan beban ekonomi keluarga dan membentuk keluarga bahagia sejahtera. Salah satu cara paling mudah dan aman dalam merencanakan kehamilan adalah dengan menggunakan alat kontrasepsi. Penggunaan alat tersebut merupakan salah satu usaha pemerintah yang menganjurkan masyarakat untuk menerapkan program keluarga berencana.

Penggunaan alat kontrasepsi selain membantu mengatur kelahiran anak, jarak dan usia ideal melahirkan, serta mengatur kehamilan akan, jarak dan usia ideal melahirkan, serta mengatur kehamilan akan merasakan berbagai manfaat. Penggunaan alat kontrasepsi dapat meningkatkan akses dan kualitas informasi, pendidikan, konseling dan pelayanan KB dan kesehatan reproduksi, meningkatkan partisipasi dan kesertaan pria pada program $\mathrm{KB}$, serta mempromosikan penyusunan bayi sebagai upaya untuk menjarangkan jarak kehamilan.

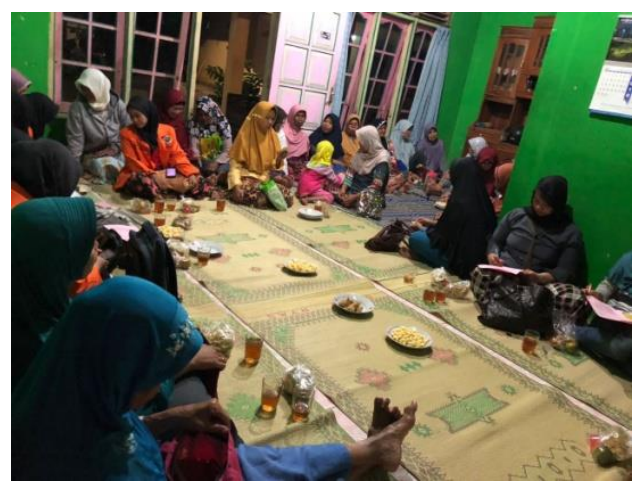

Gambar 1. Penyampaian materi tentang keluarga berencana dan jenis kontrasepsi di Desa Jambidan Kecamatan Banguntapan

Gambar 1 adalah pelaksanaan dalam proses penyuluhan berlangsung. Secara keseluruhan pelaksanaan kegiatan dapat berjalan dengan lancar, semua peserta aktif mengikuti penyuluhan dan bersemangat. Penyuluhan ini terlaksana tidak lepas dari Pemerintah Desa Jambidan yang telah memberikan dukungan dan bantuan selama proses pelaksanaan kegiatan. Serta mengerahkan warga dalam kegiatan tersebut.

Kegiatan penyuluhan keluarga berencana dan jenis-jenis ini bertujuan untuk meningkatkan pengetahuan masyarakat umumnya pada ibu-ibu rumah tangga yang berusia reproduktif khusunya untuk dapat menyadari pentingnya berperilaku hidup bersih dan sehat. Jenis penyuluhan yang dilakukan cukup mudah untuk dilakukan oleh masyarakat dan mudah dipahami oleh ibu-ibu rumah tangga khusunya.

Diharapkan dengan adanya penyuluhan tentang KB dan jenis-jenis kontrasepsi dapat meningkatkan pengetahuan ibu-ibu tentang pentingnya KB dan penggunaan alat kontrasepsi yang aman dan berkualitas. Dengan adanya peningkatan pengetahuan ini diharapkan dapat muncul sikap kesadaran dan niat untuk menggunakan alat kontrasepsi yang aman. Hal ini dilbuktikan dengan banyaknya pertanyaan yang dilontarkan oleh ibu-ibu peserta terkait tentang program KB, keuntungan dan kerugian berKB, dan efek samping dari beberapa jenis KB yang mereka gunakan. 
Dampak dari penyuluhan yang dilakukan adalah (1) adanya kesadaran untuk menggunakan alat kontrasepsi, (2) Peningkatan pengetahuan terkait KB dan kontrasepsi, (3) Peningkatan Akseptor KB di daerah setempat.

\section{SIMPULAN}

Kegiatan pengabdian masyarakat di Desa Jambidan dapat berjalan dengan baik dan lancar. Peserta antusias dan dapat bekerjasama dengan baik. Peserta aktif bertanya terkait dengan meteri yang disampaikan.

\section{UCAPAN TERIMAKASIH}

Terima kasih diucapkan kepada :

1. Universitas Ahmad Dahlan sebagai penyumbang dana sehingga kegiatan PKM ini bisa berjalan dengan baik

2. Pemerintah Desa Jambidan yang telah memberikan dukungan dan bantuan selama proses pelaksanaan kegiatan PKM

3. Ibu-Ibu Desa Jambidan yang sangat aktif berperan dalam pelaksanaan program PKM ini

\section{DAFTAR PUSTAKA}

BKKBN. (2007). Panduan Integrasi Pelayanan KB dengan Kembalinya Kesuburan Pasca Penggunaan Kontrasepsi. Jakarta : BKKBN.

BKKBN. (2008). Badan Koordinasi Berencana Keluarga Nasional. Jakarta.

BKKBN. (2012). Pedoman Pelayanan KB Pasca Persalinan di Fasilitas Kesehatan : Jenis-jenis Metode Kontrasepsi. Jakarta : BKKBN.

Handayani, S. (2010). Buku Ajar Pelayanan Keluarga Berencana. Yogyakarta : Pustaka Rihama.

Noviawati, D. (2011). Panduan Lengkap Pelayanan KB Terkini. Yogyakarta : Nuha Medika.

Perkumpulan Keluarga Berencana Indonesia (PKBI). 2010. Data Mengenai Tingkat Pengetahuan Kesehatan Reproduksi di Jawa Tengah. Semarang : PKBI.

Sulistyawati, A. (2011). Pelayanan Keluarga Berencana, Jakarta: Salemba Medika. 